\title{
Téoros
}

Revue de recherche en tourisme

\section{Tourist attractions - From natural to industrial}

The potential of industrial tourism and contemporary settings -

case the Eastern Townships

\section{Paul Fritz-Nemeth et Jan O. Lundgren}

Volume 15, numéro 2, été 1996

Patrimoine industriel

URI : https://id.erudit.org/iderudit/1075024ar

DOI : https://doi.org/10.7202/1075024ar

Aller au sommaire du numéro

Éditeur(s)

Université du Québec à Montréal

ISSN

0712-8657 (imprimé)

1923-2705 (numérique)

Découvrir la revue

Citer cet article

Fritz-Nemeth, P. \& Lundgren, J. O. (1996). Tourist attractions - From natural to industrial: The potential of industrial tourism and contemporary settings - case the Eastern Townships. Téoros, 15(2), 23-30. https://doi.org/10.7202/1075024ar 


\section{TOURIST ATTRACTIONS - FROM NATURAL TO INDUSTRIAL}

\section{THE POTENTIAL OF INDUSTRIAL TOURISM AND CONTEMPORARY SETTINGS - CASE THE EASTERN TOWNSHIPS}

\section{Paul Fritz-Nemeth and Jan O.Lundgren}

Tourism resources manifest thentselves in a a variety of ways in the physical as well as cultural environment of the destination area. In both cases the manifestations tend to define the local or regional characteristics of the destination, as they reflect the atributes of a given set of identifiable and exploitable resources. Often quite particular geographical attributes inherent in the natural landscape serve as the predicator to the spatial characterisation of a more tangible tourist product as well as a destination as such including its future development; similarly, some complement of man-made atribute in either rural or urban environnents (Lundgren, 1995) can produce spatially disrinct tourist products and successful destinations for tourist-based development, but usually on a much smaller geographic scale in terns of tourst destination space, and often located within a more extensive urban fabric, such as Vieux Montreal or the "Quartier Français in New Orleans. Hence, our ability to identify the above categories of elements as bases for local or regional tourist developwent strategies over tine produces the distinctiveness of the tourist region. As well our realisation that different tourist attractions, be they physical-environmental or manmade, tend to denonstrate different market appeal, and consequently creates a constantly changing tourist geography and tourist impacting process. This is pertinent to ou appreciation of tourist area development dynamics and growh chaaracteristics.

The analysis below focuses upon (historical) industrial-related tourist resources as they manifest themselves over one of Quebec's more well known contemporary tourist regions = the Eastern Townships especially its southern section. This new tourist-based potential has its origin in an earlier, and historically fascinating regional fame as one of the principal cradles of 19 th century countryside industrialisation occuring in regions well beyond the capital urban centres of Montreal sind Quebec. Thus, the region possesses an industrial heritage, which only in more recent years has caught the eye of both public, para-public and commercial tourist developers.
The study area incorporates a rectangular-shaped territory delimited in the west by the approximate north-south line Farnham-Mississquoi Bay (see Fig 2), in the enst by a corresponding north-south line stretching from Sherbrooke southward via Coaticook to the Vermont border; the northern limit roughly follows the Eastern Townships Autoroute. The analysis is positioned within the concept model of multiple product marketing cycles as expounded by Koller and Turner (1993: carlier atuthor's 1984 and 1969). but here adtapted to the tourist development process, and also by Bulder in his tourist area evolution interprelation (Butler, 1980). Kotler and Tumer stress the product cycle succession phenomenon, while Butler focuses more on the structural-spatial consequences of the exploitation of the principal tourist resource(=attractions) and the successively changing tourist impacting process. The sequence of new tourist products in the destination serves as a restructuring transformer agent in the development path of the tourist destination in a way that is rather similar to the product innovation notion, which aaccounts for the replacement of old products with new.

Due to regional settement history and the more recent decline of the traditional and often resource-based industrial sectors as well as the up to recently quite dynamic tourism development relying on physicalgeographic resources - lakes, mountains, beautiful scenery - the industrial heritage features of the Eastern Townships region constitute a new and rather underutilized tourist product (see Estrie Tourist Guide Book, 1990-95 for principal attractions). Thus, industrial herilage is the "new kid on the block" from a tourist product development point of view. - A classification system of the regional industrial heritage resources is attempted, which, in a preliminary sense, provides a different perspective of "the tourist geography in the region with new resources being more forcefully activated and integrated in the regional development process.

\section{IDENTIFYING TOURIST PRODUCTS}

The identification of tourist resorces in the landscape has tended to start with 
recognising the obvious prime aturactions and from there gradually descending toward objects of more marginal type (Land Capability, 1971). It may therefore be approrpriate to discuss the whole question of tourist resource identification by recognising some of the more com= mon characteristics in our way of 'looking at landscapes" in general as an entry into our subsequent discussion of industrial heritage tourist products.

The basis for our understanding of the landscape observation process has been borrowed from Meinig's by now fannous study "The beholding eye - ten versions of the same scene'(Meinig, 1979), which suggests that our perception/notions of what constitutes landscape characteristics and landscape-derived resource usige for various economic activities, including tourism - vary widely. Thus, the formulation of a spatial strategy for a regional tourist development rately is a given , but reflects upon personal attributes of the observers. This is followed by an account of how the more tradilional tourist attractions - tourist products - in the region have successively been exploited producing distinctly different locational impacts, until we arrive at the contemporary era and the need of taking a fresh look at existing potentials and exploitable tourist resources - hence the potential of industrial heritage based tourism. Finally, we should recognize the ambiguity between "industrial herilage* resources and 'contemporary' industrial tourist resources, through which existing industrial (=manufacturing) enterprises already are in the market as regional tourist attractions: consequently, we alrendy today witness a process of multiple products development à la Kotler and Tumer, even within the industrial tourist domain with an emerging new 'industrial heriage" facet. Thus, over lime, an new tourist geography as well as a more differentiated tourism impacting is emerging with geographically and locationally different regional benefits than thowe of earlier eras of tourism development.

\section{TOURISM HISTORY AND THE CHANGING TOURIST PRODUCT CONCEPT}

Tourism in Quebec provides numerous historical examples as to bow lourist attractions have changed. The reasons for such an ongoing transformation or restructuring process are always diflicult to explain. However, they are partly influenced by two factors that seem to have major consequences for any tourist development: (touristic) market appeal of specific landscape elements and accessibility. Other factors are of course also important, but they play perthans a lesser, but consequential role in the geographic impacting process brought about by tourism - societal development, urbanisation, the emergence of leisure time, popular fashions to mention a few. - Within the landscape, "specilicity" tends to be the principal "identifier" of a potential tourist product and the ability of often new transport provisions to bring tourists to the sile, constitutes a principal activaling factor, which brings the impacting process to best upon the newly identified destination.

The identilication process that inakes our attention focus upon specific landscape feature works differently for different people, a point strongly stressed by Meinig (Meinig, 1979): the historian's reflections as he gazes over al landscape scenery are very different from those of the agronomist, the artist, the economist, the geographer, the lawyer or the real estate agent. Thus, the interpretation of each person's observations always dilfers which in turn rellects the diverse development perspectives one can have "of the "same scene", the siune landscape. This process of "different seeing" can be applied to our appreciation of the tourist resource potential in any region, our study region included. If there is one common characteristies in the "process of secing" the landscape, this chancteristic might relate to the dominance of certain very basic and visually major landscape elements that jointly produce distinet and contrasting seenery - the plains-versusmountain' inferface, the water-versusland character, the rural-versus-urban, or for that matter the "old" versus the "modern" (receni).

\section{SEING THE EASTERN TONSHIPS LANSCAPE ELEMENTS}

Through its settlement history, the Fatslern Townships study region thas been influenced by the different "perceptions" of the physical landscape. Thus, notions of geographic diversity and spatial unevenness certainly influenced the judgements of early settlers in the late 1700 's- early 1800's (Hubbard, 1874, Bouchette, 1815) as it related to choice of location for colonisation purposes; ;

'distinct' topography was often viewed as obstacles to mobility - and indeed was hence its bearing upon settlement patterns, spatial access and transport (=road) infrastructure development; water resources of for instance riverine type had potentially dual functions - a water transport surface on one hand and a water power source on the other - the latter an essential factor for production and settement formation in the pre-steam power era; vegetation, especially the forest cover, was equally a multipurpose exploitable resource - for industrial-manufacturing purposes, for domestic heating and in combination with available riverbased water power providing the first seeds for the first generation of industrial,nucleated village/urban settlements; timber served also as the principal construction material after the introduction of saw mills in the region; geology depeding upon the particularity of age and strata, could in principle yield valuable minerals. Thus, reflecting the ups and downs in metal markets, mining operations were started - and closed - and started again ! Even the surface geology and soil depositions featured considerable variation, which in turn influenced agricultural practices, crop choices etc. These applications had a bearing upon farm household income, which was a function of overall yield and productivity of the farm holdings and obviously affected the appearanc of the agrarian landscape as time went by.

\section{THE SUCCESSION OF TOURIST PRODUCTS}

In touristic terms, we can observe a historical process tourist products succession (Fig.1 A-B) closely reflecting the changes in tourist preferences and local tourist resources (=attractions) dating hack to the mid 1800's (Brière, 1967): RIVERINE TOURISM preceded most other forms of tourism, and principally localed along convenient and attractive rivers, usually as they descended from 
foothills onto the flat plain, which partly related to their role as a natural transport infrastructure for passenger and freight shipping (Tulcinsky,1977) - as well as pleasant country house locations - prior to the advent of rail. Examples of the impacting generated by exploiting the riverine tourist resource are found not so much within our study region as closer to the St.Lawrence plain along the shores of the Richelieu or the Yamaska river systems at the edges of the region.

With the introduction of an inproved and more efficient mode of transport - railways- the interior of our study region was opened up. The period 1850-1890 saw the region penetrated by the railway system, practically creating an 'even' access situation throughout. The new improved access mobilised the Montreal area as a major tourist generator, and also the northeastern US, due to the interregional and cross-border nature of the railroad system. The new access situation also mobilized a new tourist product - the LAKESHORE( Brière, 1967) - which altered the location pattern of tourism : Brome Lake, the Mount Orford lakes system, the big international Lake Memphremagog, Lake Massawippi are some of the principal directions of the tourist impacting process in this era.

The most recently exploited physical environmental tourist resource is topographical - THE MOUNTAINS (Lundgren, 1983). They have served as major foci of massive capital developments since the mid $1950^{\circ} \mathrm{s}$, with, the establishment of a string of alpine ski stations. However, the mountains were recognized already in the $1930^{\circ} \mathrm{s}$ as having a touristic potential, when the provincial government established the Mount Orford Park, partly for conservation purposes, partly for outdoor nature and recreation, later, in the 1950's to be developed as a major ski centre.

The characteristics of the successive waves in the tourist product exploitation process is generalised in Fig.1 which highlights a number of features of naturebased tourist product development dynamics. Most notably one recognizes the changing longevity of ench tourist product: the product life cycle is compar= atively long for earlier products, while it shortens dramatically for producis matr-

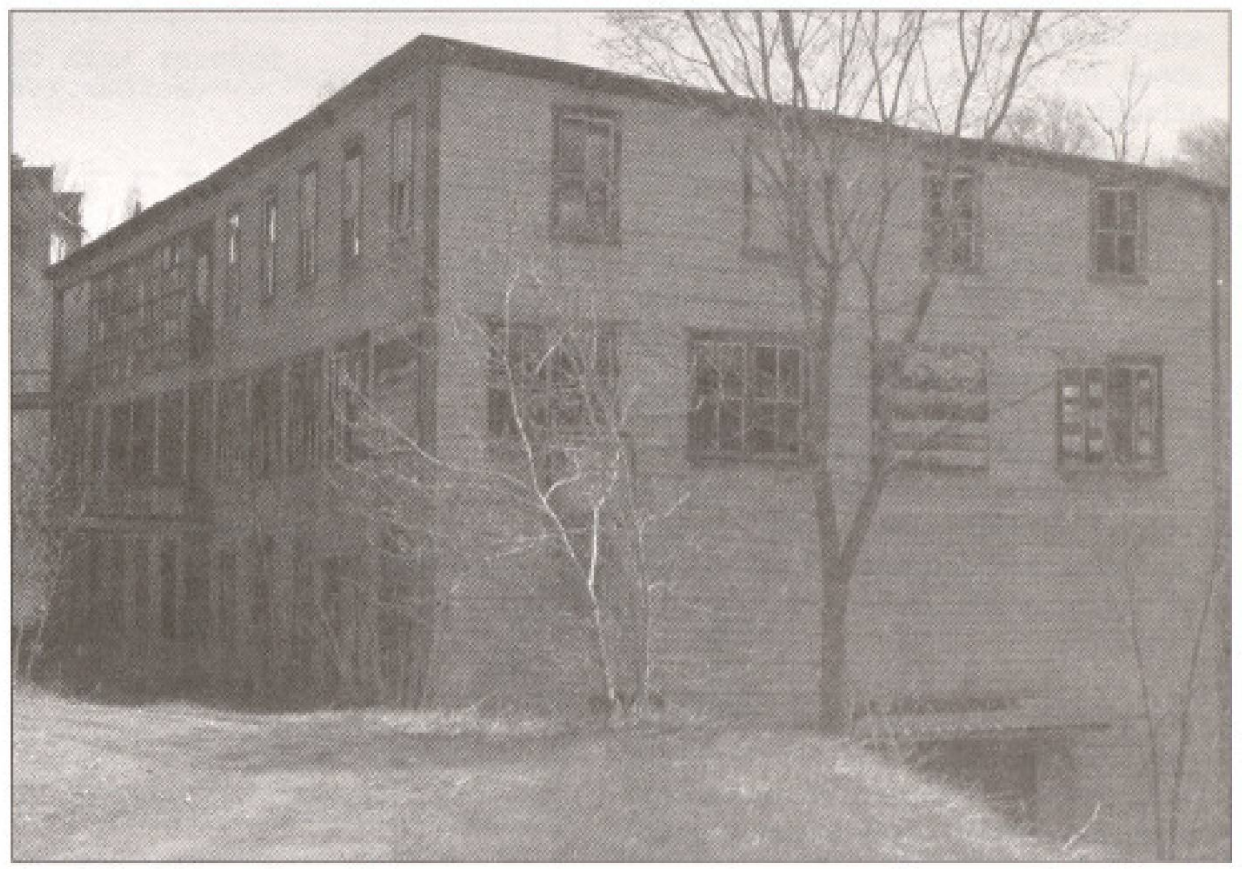

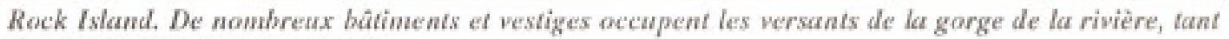
du câlé quẻbécois qu'anéricain.

keted during more recent eras. The development also accelerates over time. As well, each product cycle features a zenith, from which it gradually declines, which partly rellects the degree of resource exploitation that has occurred. Finally, one notices the compound role of all three products upon the overall regional development process: in contrast to multiple eycles of development for physical or mnanufactured products in general, most landscape-dependent tourist products, such as our set - riverine, lake-based and mountain-located - combine into an aggregate composite tourist appeal for the destination. Just because one product has "peaked" does not mean that its role in the regional tourist profile is gone. Thus, the present tourist product profile mix is very much a function of all three, which gives a diversity to the tourist utility of our study region in a way similar to the product line / model diversification strategy conmon among manulacturing company (Koller and Turner, 1993).

\section{CULTURAL HERITAGE AND INDUSTRIAL HERITAGE TOURISM}

In many respects, cultural heritige tourism and industrial heritage tourism are part of the sume phenomenon - a tourism, in which mintmade elements of local, regional or national significance constitute the principal facets of the tourist product (Annals of Tourism Research, 1996 and Gunn, 1995).

If we define the advent of modern tourist travel as the era of large volume passenger movements (for business as well as for pleasure) starting sometime in the mid $1800^{\circ} \mathrm{s}$, the cultural heritage tourist factor as such was, together with certain physical landscape features, the prime tourist attraction from the very start. Travellers flocked to famous cities - linked into the rail transport network at an early stage beautiful beaches and seaside resorts developed, (alternatively magnificent mountains and mountain resorts were established; other attractions featuring specilic uniqueness - "the highest' (Mont Blanc in Europe), the 'tallest' (the Eilfel Tower), the "only one of its kind' ( Venice, the pyrumids ), the 'mightiest' (the Niagara Falls) pulled in hundreds of thousand of visitors. Thus, the attractions that fuclled popular tourist travel during most of the era preceeding World War I were varied and represented usually a mix of culture and nature. If they were "culture", they sometimes were 'very cultural' and usually urban-based, but they could also be cultural-landscape-based - for instance the Rhine, the Hudson river or the Tuscan hill country. Few catered to the engineer tourist, or the architect 
tourist specifically. Thus, few tourists cared about the industrial heritage directly, although the achievements of industry often were acclaimed attractions in their own rights but also for what they represented as historical landmarks - the Eiffel Tower, the Tower Bridge, the Statue of Liberty, Via Appia. The often dilapidated remains of bygone eras production facilitics = old mills and factories - are conveniently overlooked, unless they find a spotlight as potential restoration objects. Only little by little have we seen new forms of tourism emerge, in which less obvious attractions, such as remains of the industrial past have been put into use more effectively from a touristical point of view.

In our rapidly changing world we see the "past" disappearing at an abaming rate, which may partly explain our sudden interest in not only the fairly obvious culturat heritage features, they be traditional culinary habits or the historical urban landscape, the old theatre, the old bridge, the old mill or for that matter the old industrial milieu. The pace of change, obviously, is a powerful force behind our discovery of the "past' as a tourist attraction - we are no doubt loosing too much history too quickly -hence our concern for 'rescue operations' in the form of various local or national-based preservation/ restonation policies.

However, there is another factor that has mobilized our interest: the economic need of tourist regions, they be cities, smaller urban centres or rural enviromments, to diversify their respective product range, in the process mobilizing any landscape element with a potential touristic utility. As demonstrated earlier, tourist regions exploit their tourist resources by a process of "successive elimination" of more obvious and visible, and more popular attractions. Hence, at some point in time the destination reaches a stige of 'attraction depletion'( Fig. 1), a situation that only can be overome by either the creation of "new' manmade attractions Disneyworld is a prime example or, if the region cannot afford such an extravagant capital investment, by the imaginative identification of underused or overlooked historic resources not yet effectively mobilised as tourist attractions. This usually means that a preparatory cultural- historical inventory process swings into action, eventually discovering a plethora of potential items as well as making reconmendations to public authorities on matters pertaining to the sel-

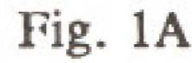

TOURIGT AREA CYCLE OF EVOLUTION

(Butler, 1980, nodified)

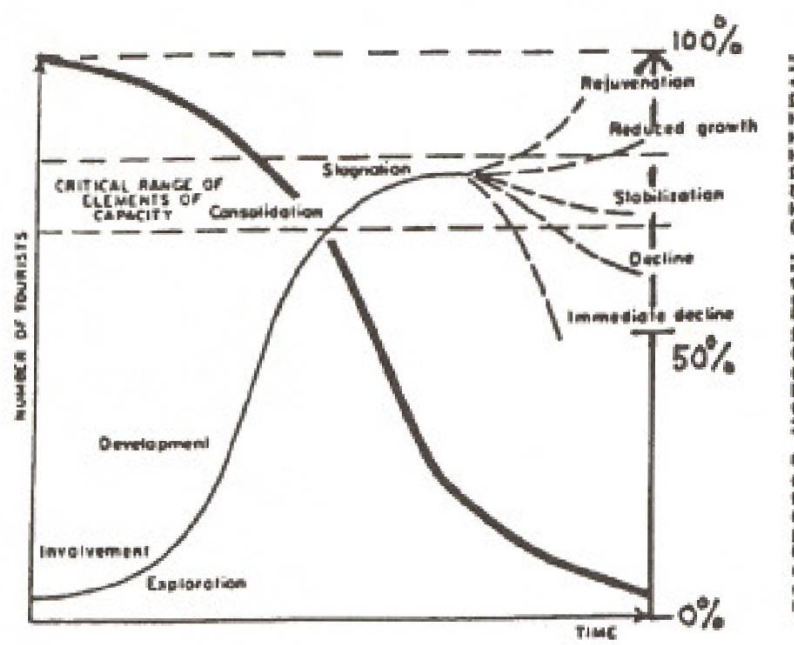



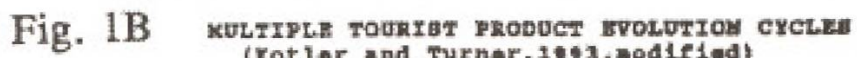
(Kotlor and Turmer, 193, modified)

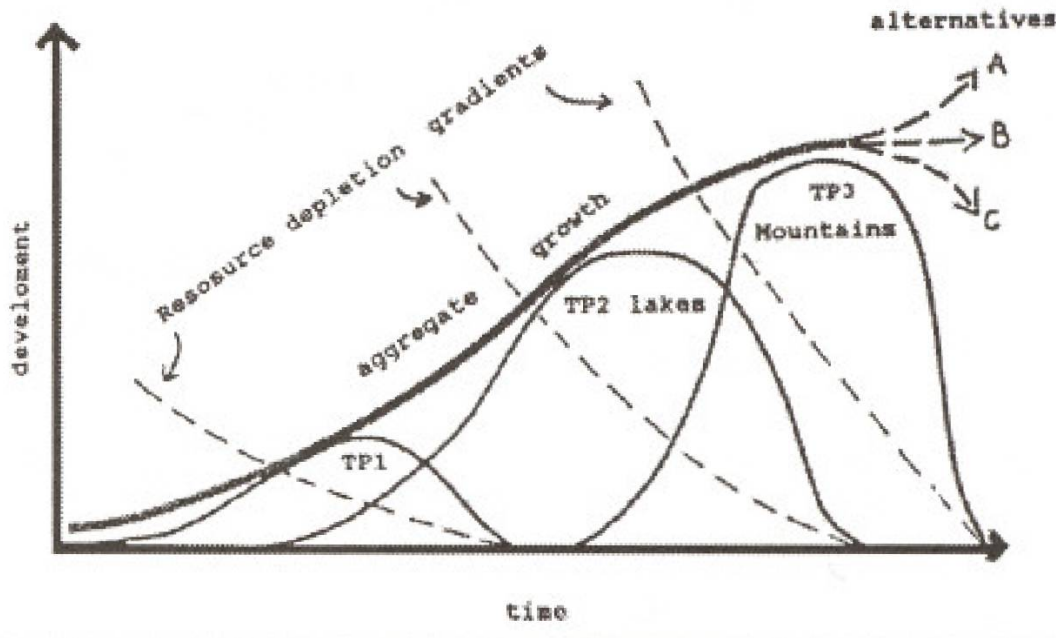

ting up establish institutions in the form of museums, historical moiuments, buildings and event landmarks. Thus the cultural heritage is activated and incorpotated into the touristical 'image" of the destinstion.

\section{IDENTIFYING THE RANGE OF INDUSTRIAL HERITAGE ATTRACTIONS}

The effort to identify "new" cultural heritage derived tourist atractions in the destination region includes oday, in a very active way, also the industrial heriage (Lachine (anal,1994), For instance,
Quebec MRC planning documents produced during the past 15 years incorporate, where appropriate, a variety of patrimoine locations that sometimes can be categorised as "industrial heritage'( Le Patrimoine industriel,1985). Similarly, the Quebec Ministry of Cultural Affairs has systematically inventoried regions and municipalities, in the process drawing attention to a wealth of historically exciting cultural heritage and industrial heritage phenomena .

For our purposes, it is useful to establish a framework of inventory and analysis of the industrial heritage as it presently manifests itself in the study region. The classification 
Fig. 2 nNDUSTRAL HERTAGE LOCATIONS

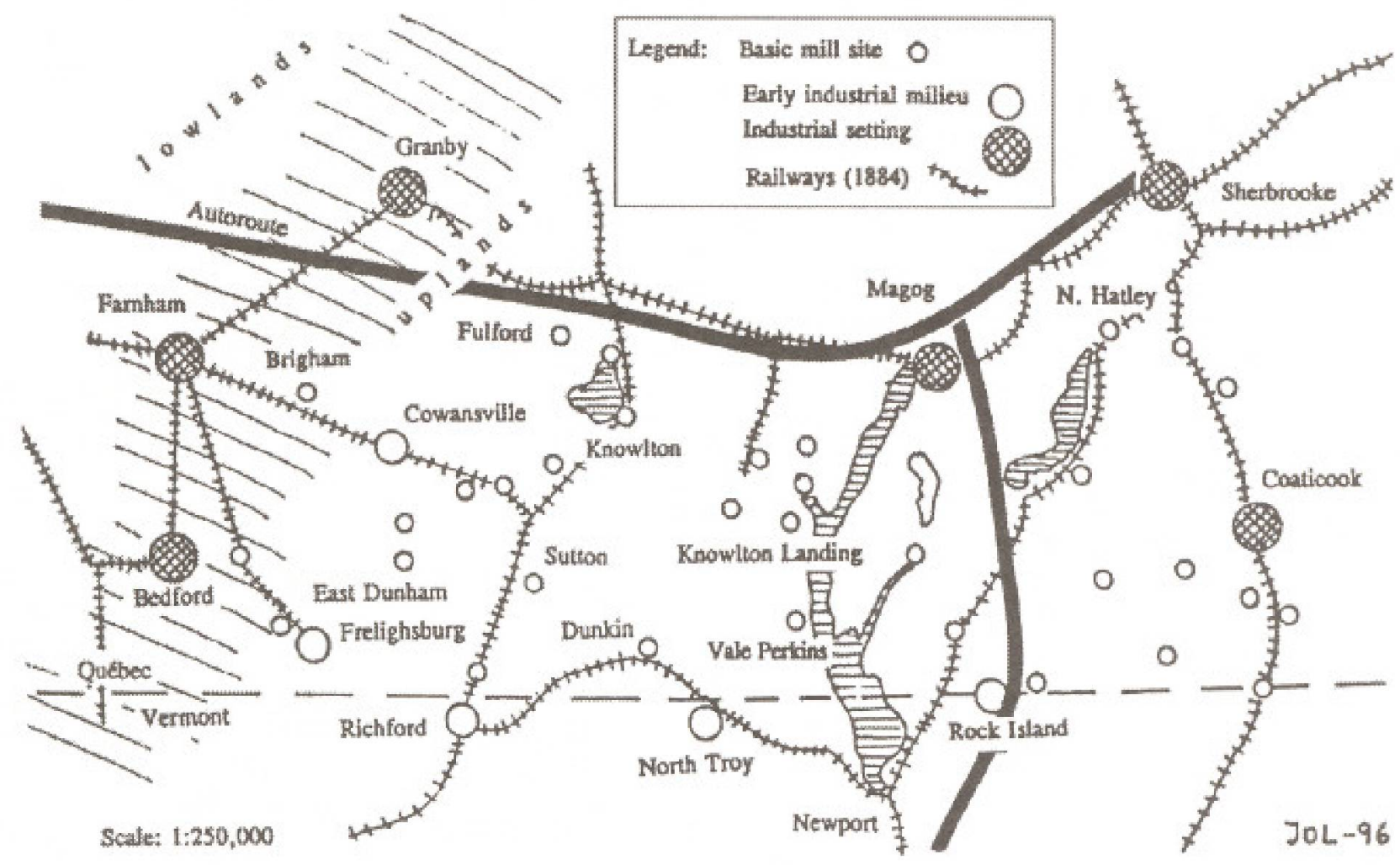

outlined below is tentative and focuses upon 'maunfacturing' facilities, which means that a wide range of other types of industrial heritage items are excluded, for instance transport infrastructures (bridges, canals, historical railways) - The main purpose of categorizing (Gunn,1995, Annals of Tourism,1996) historically important manufacturing facilitites is to arrive at a rational differentation of locales globally, which may be important from a tourist marketing and developmnent strategy perspective. In addition, it would also indicate different levels of signficance in terms of tourist utility for the region. Underlying the classification lies the notion of "uniqueness": some types of potential 'industrial heritage' attractions are fairly common throughout the study region while others are "more unique" and therefore, if launched as a tourist site, might have a better chance to establish themselves as tourist attractions of higher order, drawing visitors from farther afield. Thus, the classification stants "on a basic level' and moves successively toward higher order industrial heritage attractions, all placed within a hierarchal

structure.

\section{A.THE LOCAL AND BASIC CATEGORY - THE SMALL INDUSTRIAL SITE}

It was noted earlier that the agratian settlement process in the study region was initiated in the 1790 's and with some minor exceptions finished only around 1900. - A major locition factor in this development of a system of small nucleated settlements was river-based waterpower, an essential inpul for the earliest "manufacturing" operations in the region, notably the grist mills, the saw mills, the planing mills (Historical Atlas, 1881). Thus, the historical 'mill sile' is an omnipresent industrial heritage feature of the Eastern Townships landscape (see Fig.2) and usually dates back to the very first era of setlement. Today, the small physical dimensions of these sites completely tail to give credit to their earlier local-economic and industrial significance as they of ten lave fallen into disre- pair as their market bases gradually dissappeared and hence their raison d'être. Alternative energy sources, above all hydro-electricity, were usually the culprit. At some sites one can still study the dam constructions with their impressive foundations for water wheel positions; if such features have dissappeared, field stone blocks at the steep slopes of the small river or brook tell the tale of past industrial activity on the site. Examples abound, from the rather intact mill site and pond at Stanbridge East (now part of the local museum) west of Dunham, to the grown over saw mill site operation in the intersection of Cooledge and Mountain roads in the Knowlton Landing area, the Vale Perkins brook at Owl's Head, or east of Lake Memphremagog the sites at Comestock Mill, Way's Mills, Judd Mills, and Baldwin Mills, to mention some. - The historic significance of these small and numerous locales may be lost to the average tourist glancing down at the water gushing over the dilapidated spillway and cracked dam wall, however, these small industrial processing enterprises functioned as the principal local ser- 
vice points to which the first-generation settlers-tumed-farmers brought their harvest for milling or their timber loads for sawing while at the same time buing some necoessitites in the nearby "general store".

The omnipresent small industrial site once found throughout the study region usually consisted of a singular installation that combined into the specific production function - the dam, the waterpowered wheel and a set of specialised implements essential for the processing (the saw, the milling stones, the hammering device). The physical dimensions of the enterprise were modest as it reflected the dimensions of the waterflow harnessed in the stream or small river. Indeed, the small dimensions of the stream usually decided wether the the installation could be built in the first place, given existing 'engineering' skills and methods of construction. Still, the sites, once in operation, played an important role to the settlers in the vicinity and gave areas possessing even quite modest mill sites a competitive comparative edge over other areas without water power. Only with improved access to alternative power sites were the small sites gradually abandoned.

\section{B.EARLY INDUSTRIAL MILIEUS CATEGORY}

The industrial milieux represent much more of a local industrial development and potential industrial heritage experience than the small individual (grist) mill sites referred to above. Although in most cases initiated at the same time - usually in the first half of the 19th century - the industrial milieux developed into more important urban centers, economically and socially, and persevered over a much longer period of time. Many still show vestiges of past industrial glories, often in the form of ruined buildings or crumbling dam structures but also in an indirect way, in the impressive private residences in the surrounding urban-residential settlement, all reflecting the accumulation of local personal wealth of a bygone era. Usually the towns lost their industrial competitiveness with the arrival of railways, which exposed them to large-scale extraregionally located industrial competition unless some very specific resource endowment still gave them an economic advantage. Sometimes the individual industrial enterprises survived for another couple of decades on their own business acumen and ingenious entrepreneurship, but, in the long run, the fate of these industrial centers was inevitable. Although World War I boosted local industry through government contracts, the subsequent trend was 'downhill". These towns are nevertheless visible industrial heritage attractions which usually is recognized in the written accounts of local history in regional guide books or locally produced pamphlets. However, in many cases the factory structures are gone - sometimes destroyed by fire, sometimes by the forces of nature. In other cases a certain degree of restoration work has helped to give them a lease on life as tourist attractions, but usually on a modest scale.

Among the early industrial milieu locations are found urban centres of considerable historic prominence in the region, such as Cowansville, Freligsburg, Mansonville and Rock Island-Stanstead. Among them, Rock Island has perhaps the most interesting industrial history, in spite of its present-day small population; since its founding as a border lown around 1800 and the inevitable establishment of gristmills in the Tomifobia river gorge, the town experienced an industrial diversification that for a long time was unmatched anywhere in southern Quebec (Lundgren,1991), except for towns closer to Montreal. In fact, Magog ( Story of Magog, 1951) and Sherbrooke were industrial latecomers by comparison !. The economic synergy in Rock IslandStanstead's border location - with industrial smuggling as an obvious sideline sustained a remarkable industrial growth during the first half century, including early metal transport stock products, a variety of clothing factories, saw mills, paper production to mention some - all centred on very skilful, initial, harnessing of the water power in the deep river gorge that practically cut through the area of the future urban centre. Most of the old industrial installations have disappeared by now, but the industrial herilage as well as the historic character of the residential quarters on both side of the horder line have been recognized as major tourist attactions by town councils and the local historical museum. The tourist visitor volume in the area has been on the increase during the past couple of years. - The number of locales of 'industrial milieu type' is relatively small but they can be found on both the west and the east sides of the Lake Memphremagog (Fig.2.) and also immediately south of the border in Vermont, where notably Richford, located south of Abercorn, and North Troy, immediately south of the Higwater border crossing, qualify.

\section{C.LARGE-SCALE INDUSTRIAL SETTINGS CATEGORY}

As we climb the hierarchy of industrial heritage sites and locales in the study region the number of identifiable locations narrows - a logic that applies to any hierarchal structure. Even a very generous inventorying of the previous category does not yield more than perhaps a dozen locales of interest both in terms of overall local history and 'industrial' significance.

The final and the most outstanding industrial heritage locales in the region are few and represent in many ways urban centres that both historically and also today possess major urban-industrial functions, however, not necessarily of the same type that made them rise to historic prominence during the 19 th century. Typical for them all is the fact that many have kept the original industrial architecture - and it is sometimes even still used. Thus these industrial milieux have yet to become 'museal', which poses a problem per se, actually, from the point of view of them also serving as a tourist attraction.

The outstanding locale in this category is Sherbrooke, where, along the river gorge, the industrial development once was massive (Eastern Townships Gazetter and General Business Directory, 1867) and more permanently built than was the case in Rock Island. The Sherbrooke industrial milieu is a highly visible industrial-historical manifestation, which has been recently recognized through the upgrading of the gorge for visitor purposes with self-guided interpretation walks. In other words, through local intitiatives a new 'iourist product' has been added to the city's other attractions. Here we come close to the restored industrial heritage milieus of Lovell, Mass. and of other New England mill towns in terms of scale and overall atmosphere, but still lacking 
in many respects the range of economic activities that could further its role as an industrial heritage locale of a higher order. - Granby, Coaticook and Magog represent a second tier within the industrial settings category. Magog, originally called "the Outlet", has perhaps the most dramatic entrepreneurial history, based on its dual role as a strategically located historic service centre and distribution point for the lake region settlements prior to the arrival of rail services through an extensive waterborne transport system operating from the town beach and an early development of a locally owned cotton mill, that at the turn of the century became part of the Canadian textile giantDominion Textiles Corporation - in the first modest industrial damming of the Magog River just at the western end of today's Rue Principale some time in the $1870^{\prime} \mathrm{s}$. - Coaticook on the other hand could only exploit its impressive gorge after the improved access situation through the construction of the Sherbrooke-Island Pond (Vermont) railway line. This linked the location with the rapidly industrialising and urbanising zone along the St.Lawrence river on the Canadian side of the border and southwest with Portland, Me. Coaticook rose quickly to the fore as a textile dominated town, retaining this character well into the post World War II period. Since the demise of these establishments, the actual physical site in the gorge has been converted into a major tourist attraction with some 150000 visitors annually. Granby, finally, a typical fall-line location town on the Yamaska river, similar to the Farnham and Bedford sites, developed into a multiple-industry town with textiles, furniture and more recently agroindustry, as many of the other towns. The town benefitted also from its interfacing location between upland and plain on the edge of the St.Lawrence plain. Some tine industrial architecture can still be seen along the river side in the town centre; the scale is smaller than that of Sherbrooke's imposing structures, but very consistent and compact in its overall appearance. More recently, the city has emerged as Canada's largest agro-industry location (Agropur Inc. and related enterprises), which already serves as a well-established industrial tourist attraction in its own right, but to some degree lacking historical and museal patina.

\section{IMPLICATIONS OF THE INDUSTRIAL HERITAGE LOCATIONS}

The overview presented above suggests that the study region possesses a considerable variety of industrial installations covering a remarkably long historic development. The touristic utility of these locales in their often idyllic settings is hard to assess given the market's major preoccupation with more popular and well established forms of outdoor recreation both in summer and winter. Lakebased tourism, mountain-based tourism and recreation and general excursion tourism as a function of convenient access into the region for the Montreal area population have in a sense permanented the touristic function and utility of the region no doubt also for future years.

Any changes in the touristic function of the study region will be hard to introduce. Or are they ? During the past decade, or even during a longer period, new trends of tourism have been emerging, not always industrial heritage-related, but nevertheless indicative of the continuous demand/supply shifts occurring in the region's tourist image. For instance, the cultural tourisin factor is on the increase sometimes through "festivals" for different seasons (usually nature-related), sometimes exploiting the excursion market among Montrealers -as is the case with the summer and in sone instances year-round stage theatre enterprises that now are in their third decade of operation. Also, during the past couple of years the crafts and fine art studio entrepreneurs have established themselves throughout the areat, attracting town and city people both summer and winter time. To these could be added the vineyards development in the Dunhaun area, presently drawing some 25000 day visitors during the early fall (Lundgren, 1995). Thus, the role of the traditional lake-and-mountain attractions, although still preeminent through the popularity of beaches, lakeshores and eflective verticals of ski hills is gently modified, although not challenged.

The industrial tourist product - be it the historical fetalures discussed carlier or the contemporary industry sectors locatted in the study region is altracting tourists, a mix of regional tourists ats well as poople coming from other regions, and is, in the process, bringing about subtle shifts in visitor travel patterns and through that a change in the spatial circulation of visitors and tourist dollar expenditures. Perhaps these shifts are on such small scale that they do not matter to any major degree, but they do nevertheless bring about a change in the manner in which the regional tourist product elements function and impact different corners of the region.

The essential information about industrial heritage tourism has yet to be proper recognized in the Eastern Townships regional guide book, in which general touristic information seems to dominate with little, if any, reference to what once made the place develop and grow. Seldom is the reader informed about for instance the age of villages or smaller towns, except in an oblique manner; rarely is reference made to the industrial origins that carried the growth of the place, nor to the industrial vestiges still quite visible in many urban environs. The magnificent industrial gorge in Sherbrooke is not even mentioned; the past glories of the similarly impressive Rock Island gorge deserves some mention as an industrial establishment of a bygone era. Thus, the visiting tourist population is not effectively informed through the most commonly used information source about the principal local aspects of the region's industrial heritage. The regional section on the "patrimony" excels in saying little of regional importance, except re-stating banalities about the rich built-up heritage, villages located at rivers and the odd covered bridge or round barn!

Given the above deficiencies in the normal channels of tourist information on the region, it is time that the regional tourist "administrators" and information personinel woke up to the importance of the industrial heritage as it manifests itself on the village level, or in the small town, or in a regional capilal such as Sherbrooke. It is through this heritage that the urban settlement system once was established and grew - and at the same token, at a later stage declined, The images of industrial history more than any other aspect shaped and altered the region during some 150 years ! 
The contemporary industrial tourism phenomenon should also be considered when viewing the regional potential for further touristic diversification. To a degree, the existing industrial enterprises, both big and small seem to recognize the importance of "promotion"; hence, many of the more well-established industries are open to visits by the public. No doubt these factories or industrial processing plants attract considerable visitor numbers from which the towns may benefit further: the Agropur industrial complex in Granby is one example of a major contemporary "industrial" tourist attraction; a similar one are the numerous active granite industry ateliers in Beebe, a local attraction that is practically unique to Quebec as a whole. Thus, if we combine the industrial heritage component with the contemporary industrial plants as a systematically promoted system of tourist visitations the tourist profiling of the study region will be more dramatically modified - and the benefits of the tourism phenomenon more effectively diffused throughout the region.

\section{BIBLIOGRAPHIC NOTES}

ANNALS OF TOURISM RESEARCH, 1996, Vol.23, No. 2, Heritage Tourism. See particularly the article by J.A.Edwards and J.C. Llourdes I Coit: "Mines and Quarries - Industrial Heritage Tourism", pp. 341-363.

Bouchette, J.s 1815, "Topographical Description of Lower Canada", Canada East Reprints. St.Lambert, Que,

Briere,R., 1967, "Les Grand Traits de l'Évolution du Tourisme au Quebec", Bulletin Num. I de l'Association des Geographes de l'Amerique Francaise, pp.83-95.

Butler, R.W., 1980, "The Concept of a Tourist Area Cycle of Evolution: implications for management of resources", CANADIAN GEOGRAPHER, XXIV,1,pp, 5-12.

Eastern Townships Gazetter and Business Directory, 1867, St.John, "Lower Canada", pp. $56-70$.

ESTRIE TOURIST GUIDE (BOOKS), published by I'Association Touristique Regionale de l'Estrie on an annual basis.

Gunn, C.A., 1995, Tourism Planning, New York, notably discussion on classification of tourist artractions.
Historical Atlas of Quebec Eastern Townships 188I, H. Belden and Co. (Reprint, 1972).

Hubbard, $\mathrm{B}, \mathrm{F}, 1874$, Forests and Clearings - the History of Stanstead County. Montreal.

Kotler, P. and Turner, R.E., 1993, MARKETING MANAGEMENT, Canadian 7th Edition, Prentice Hall Canada Inc.. See particularly pages 371-397 re:"product life cycles".

LAND CAPABILITY FOR RECREATION, 197/, "Canada Land Inventory, Department of Mines and Resources", Ottawa. Map Sheet Monireal 31 H.

"Le Patrimoine Industriel au Québec, 1985", Commission des Biens Culturels du Québec. Rapport prepared by Lousie Trottier.

Lundgren, J.O., 1995, "The Tourism Development Process in the Eastern Townships", Paper presented at the L'ACFAS Conference, Université du Québec, Chicoutimi, May 1995, $22 \mathrm{pp}$.

Lundgren, J.O., 1991, "Border industrialisation: the case of the Eastern Townships' Towns Standstead - Rock Island - Beebe mid I800's to mid 1900 's", in RURAL AND URBAN FRINGE STUDIES IN CANADA. K. Beesley (editor), Geographical Monographs, York University Atkinson College, No, 21, pp. 269-281.

Lundgren, J.O., 1983, "Development Patterns and Lessons in the Montreal Laurentians", Chapter 5 in TOURISM IN CANADA, P. Murphy (editor), University of Victoria, Victoria, B.C.

Lundgren, J.O., 1988, "Tourist Destination Development and Problems of Management: case Lake Memphremagog Region", TEOROS, V.7.No.2,pp.11-16.

Meinig, D.W., 1979, "The Beholding Eve - Ten Versions of the Same Scene", in THE INTER. PRETATION OF ORDINARY LANDSCAPES, Oxford and New York City,

"Mise en Valeur du Canal de Lachine et Faisabilité d'un Train Lachine/ Vieux Port", Atelier multidisciplinaire, N/Ref.400, Communaute Urbaine de Montréal, Juillet 1994.

"Story of Magog, 1951", (=Commercial and Industrial Story of Magog by Alexandre Paradis, Magog).

Tulcinsky, G., 1977, The River Barows - Montreal Businessmen and the Growth of Industry and Transportation 1837 - 1853, Montreal.
Colloques et Congrès, no 9:

\section{LE TOURISME D'AVENTURE}

Le neuvième numéro de la collection Colloques et congrès publiée par Téoros paraîtra en septembre 1996. Il rend compte du colloque québécois sur le tourisme d'aventure qui s'est tenu au Mont-Tremblant les 2 et 3 mai dernier.

Sous le thème: 1996, l'année de tous les risques, une vingtaine de personnes ont apporté leurs connaissances et leur expérience pour faire le point sur le tourisme d'aventure dans le monde, au Canada et particulièrement, au Québec. Les ateliers, au nombre de 6 , furent l'occasion d'approfondir le concept mểme de tourisme d'aventure et tous les aspects de la création et de la mise en marché de ce produit touristique. L'événement a été organisé par le Centre d'expertises touristiques des Laurentides avec la collaboration de l'Association touristique des Laurentides et de plusieurs organismes publics oeuvrant dans la région.

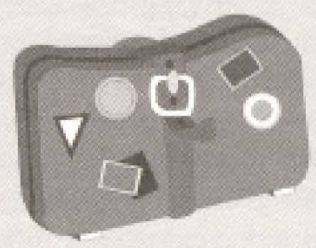

